\title{
Entrepreneurship Drivers in the Non-farming Sector: Rural-Urban Contrast
}

\author{
Abebe Ejigu Alemu ${ }^{1}$ and Dereje Teklemariam ${ }^{2}$
}

\begin{abstract}
Using data from 5262 households, we explored entrepreneurial drivers in the non-farm sector. Marital status, religion, ethnicity, education type and the size of the household plays different roles for rural and urban households' engagement in non-farm enterprises. In both urban and rural areas, household size is a driver to non-farm enterprise engagement. Shocks in the household such as illness drive rural households to engage in the non-farm enterprise sector. However, drought restrains the participation of rural households in nonfarm businesses. Divorced households engage more in enterprises. Unmarried households, however, witnessed less involvement in the sector and it is significant for rural households. Urban illiteracy and rural primary education significantly determine households' involvement in the non-formal sectors. Moreover, the study identified a non-linear relationship between age and enterprise engagement where engagement in non-farm enterprises increases with age up to 58 years and then declines and it is significant for urban households. In the case of urban households, male-headed households are driven to non-farm engagement. Understanding variations in marital status, socio-economic make-ups, entrepreneurial training, and education can be plausible areas of intervention to adequately understand both the entrepreneurial ecosystem and strengthen the non-farming entrepreneurial sector livelihood.
\end{abstract}

Keywords: Entrepreneurship, Non-farming, Rural, Urban, Drivers https://dx.doi.org/10.4314/ejeb.v6i2.5

\footnotetext{
${ }^{1}$ Department of Management, College of Business and Economics, Mekelle University Corresponding author: Abebe Ejigu, abebe.ejigu@mu.edu.et/abebeejigu@yahoo.com

${ }^{2}$ Department of Management, College of Business and Economics, Mekelle University
} 
Entrepreneurship Drivers in the Non-farming Sector

\section{Introduction}

There is wider recognition on entrepreneurship as an engine to economic development through self-employment, enterprise creation and innovation. There has been a surge of interest on entrepreneurship during the global financial and economic crisis towards the creation of self-employment opportunities and make countries resilient to economic shocks (Smith and Bagchi-Sen, 2012). Entrepreneurship also has the capability to attract the emerging markets which are searching for options for growth other than exports and foreign direct investment (Fayolle, 2007). As the economic crises affected the globally integrated countries, policy makers revisited their policy focus and devise strategies in favour of entrepreneurship with a belief that they largely serve the domestic and regional demand. Despite the increased interest on entrepreneurship, the achievements, and the entrepreneurial culture, the literature substantiates only scant knowledge regarding the entrepreneurial drivers in the developing world particularly in rural areas (Ingstrup and Christensen,2017; Brixiova and Asaminew, 2010).

Entrepreneurship is allied with human's engagement in innovation (Drucker,1984) and activities of business nature involving financial risk for profit (Marlow and Swail,2014). The modern thinking of entrepreneurship began in the eighteen century with the development of business and capitalism. Currently, entrepreneurship is related to individual, corporate and social undertakings, implying the evolution and the growth of the concept. The conception of entrepreneurship evolves across periods and is not limited to a single definition although the notions constituted components of uncertainty, innovation, economic efficiency, the theory of the firm, and economic development (Ricketts, 2009). As a result, it attracted several disciplines such as economics, management, sociology, engineering and psychology.

An entrepreneur is a person who engages in an enterprise of commercial nature at personal financial risk and the one who sets up a business by taking own financial risks in the hope of making profit (Aliaga-Isla and Rialp, 2013).Entrepreneurship in economics is one of the important resources in addition to land, labour, and capital as entrepreneurs uniquely combine the three basic resources to produce goods and services with value to the society and make profits (Williams, 2009). Hence, entrepreneurs are considered crucial to the growth of the economy.

Entrepreneursfoster innovation and economic growth to benefit themselves, society and nations at large. Entrepreneurs plan business, employ labour, acquire required resources and provide leadership and management to business. It involves the designing, launching and managing of new ventures 
that are prominently small start-ups given expanding and sustaining it in the long future. The business is to offer products or services to market for sale in anticipation of profit and sustaining for long. For this, Schumpeter referred to an entrepreneur's role in the economy as 'creative destruction' which is the heart of innovation and the vehicle for economic growth through incessant product and process innovations that simultaneously replace old industries while ushering in new industries and approaches (Schumpeter 1942; 1965). For him, an innovative entrepreneur launches changes and disequilibrium in the economy and it is considered a character and norm for the healthy economy (Drucker1984).

Entrepreneurship focuses on launching new businesses which involve high level of risk for which many of the entrepreneurs fail and close their undertaking shortly after establishment due to changes in the market, economic environment, and fluctuations in prices, problems of finance and bureaucratic procedures and problem of hiring talent from the labour market (Marlow and Swail 2014). The concept of entrepreneurship is expanded not only to cover launching of a new business but also identification and evaluation of opportunities, how to exploit them, use these opportunities, develop products, create wealth and sustaining in business through innovation in various stages of the product life cycle. Entrepreneurship is notably associated with creation and launching of small business; but it is crucial in profit and not-for profit, medium and large-scale organizations, voluntary sector groups, charitable organizations and government (Drucker, 1984). Currently, the field of social entrepreneurship is widespread, which involves entrepreneurs combine business activities with humanitarian, environmental or community goals.

Entrepreneurship is a critical driver of innovation and economic growth. Hence, promoting entrepreneurship becomes an integral part of the nation's economic growth strategies in many local and national governments around the world (Hjorth, 2013). To this end, policy makers commonly assist in the development of entrepreneurial ecosystems where entrepreneurship operates, which may include entrepreneurs, venture capitalists, and governmentsponsored programs to assist entrepreneurs (Guerrero and Pena-Legazkue, 2013). These may also include non-government organizations, such as entrepreneurs' associations and education programs. Government programs include technical and financial support to promote business start-ups. Nongovernmental or quasi-governmental organizations such as academic institutions and professional associations provide training, business counselling and mentoring services to nurture entrepreneurship. Both government and nongovernment organizations will create an entrepreneurship eco-system by 
arranging such resources and facilities as business clusters, business incubators, entrepreneurship education and training, provision and facilitation of loan and access to funds and grants, and eliminating bureaucratic hurdles and inhabiting rules and regulations (Harper,2003).

Entrepreneurship enhancement is of great importance in developing countries as they are engines for development. Many developing countries are dominated by agri-based economies with which the largest portion of their population depends on agriculture. Entrepreneurship will foster innovation and non-farm engagement which transforms rural economy and improves the livelihood of the rural population (Zuwarimwe \& Kirsten, 2011; Kirsten, 1995; Shehu et al.,2014). The rural economy depends predominantly on agriculture and participation in non-farm business sectors would reduce dependence on agriculture and pressure on land and natural resources. This would foster more rural employment and promote rural-urban linkages. It mitigates rural-urban migration and stimulates value creation. Entrepreneurial innovation, micro, small and medium-sized enterprises are socially and economically important to a nation; however, the number and diversity of non-farm businesses in rural areas is so small to attribute to significant socio-economic transformation in the rural areas (Kirsten, 1995). Entrepreneurial innovation and rural non-farm economy is crucial in rural areas of the developing world as they are key sources of new jobs for the rapidly increasing agricultural/rural labour force (World Bank 2008).

The concept of entrepreneurship is not different in theme and substance in rural and urban areas, rather the entrepreneurship ecosystem in urban areas may be well supplemented with closer government support, market, educational and professional association (Bergmann and Baumgartner 2010). The rural entrepreneurial ecosystem is constrained regarding infrastructural access, market and credit providers affecting the launching and sustainability of rural enterprises. Entrepreneurs in the countryside are far from the market, business development support, financial institutions which may hinder start-ups and success of rural entrepreneurs. However, as large part of the population are in the countryside, promoting entrepreneurs and fostering entrepreneurship ecosystem will play a crucial role in improving and changing the lives of the rural community where poverty is rampant. As Fieldsend (2013) stated, development strategies in the developing world should include rural renaissance component which helps to achieve resilient economy.

Entrepreneurs in the rural areas are different from urban areas in that a rural entrepreneur is merely someone who is limited to stay in the rural area and 
contribute to the creation of local wealth. In rural areas, families are highly extended where entrepreneurial effects are to the extended family and the community; which may limit the sector at micro or small-scale supplementing households' income rather than financing the expansion of the enterprise. To this end, rural entrepreneurship is highly interlinked with rural development endeavour in diversifying alternative income sources to the household. The effect of rural entrepreneurship is to reduce poverty, improve livelihood reducing inequality. Hence, rural entrepreneurship is labelled as communitybased having strong extended family effects and greater impact on the rural community (Fieldsend et al., 2010). It is also reflected by the type, size and diversity of firms as most of the rural entrepreneurs are engaged in micro and small-scale non-farm and agricultural businesses that contribute more to the household economy. Rural entrepreneurs are primarily natural resource dependent.

Nearly $60 \%$ of the population in Sub-Saharan Africa is rural and agriculture dependent. People are largely in poor livelihood conditions. Innovation and fostering entrepreneurship are keys to improve non-farm enterprise engagement which is central to development policy as it diversifies household livelihood strategies. Nevertheless, in African countries including Ethiopia, spending in agriculture is widely focused and remains a central theme in development discourse (Fayolle, 2007). More than 80\% of the country's population in Ethiopia is rural, and rural poverty is widespread. Many factors are raised including for the rampant rural poverty such as high rural population densities and land shortages, recurrent droughts, variable rainfall, and declining soil fertility, high variability of agricultural production, limited access to modern inputs and infrastructure, and limited output market (Spielman et al.,2010).

Smallholder agriculture is the main feature of Ethiopia which left farmers to supply small amount to the market (Abebe et al.,2016). The intensive intervention in extension services for the last decade has improved productivity and improves market orientation and link to market. However, the non-farm sector engagement has not shown significant improvement to bring visible economic changes among the smallholder farmers. Non-farm engagement is regarded as an engine in transforming the rural economy by improving income, creating employment and fostering market linkages and minimizing ruralurban migration (Lanjouw and Lanjouw, 2001). 
There is also a significant rate of urban poverty in Ethiopia, and the government has made an intervention in promoting households to engage in micro and small enterprises. Nevertheless, the level of unemployment and migration of citizens remain a challenge and alerts policymakers to design policies such as enhancing entrepreneurship in both rural and urban Ethiopia. Despite the extensive efforts to create an entrepreneurial ecosystem by the government, non-government and training and educational institutions, it fails to address differences in the situations of rural and urban enterprises regarding type, diversity, and determinants to non-farm engagement. The aim of this paper is to characterize households and investigate drivers for families' nonfarm engagement; i.e., to answer the question 'what are the socio-cultural and socioeconomic characteristics that derive rural and urban entrepreneurs to engage in non-farm enterprises?'. The study characterises rural entrepreneurs and urban entrepreneurs in terms of social, cultural, demographic, ethnic and location related (urban-rural) determinants by taking World Bank's Living Standards Measurement Study data which was collected in the year 2013 throughout the whole country covering 5262 households.

The study provides input to policy makers in identifying important determinants of non-farm engagement in the rural and urban areas so as to create an entrepreneurship ecosystem which could foster both rural and urban entrepreneurs. Entrepreneurship ecosystem is prominent in the rural and urban economy as it promotes value creation through recognition of business opportunities, and mobilizes human, financial and material resources. To properly create an entrepreneurship ecosystem to foster rural and urban economic transformation, understanding the characteristics of households participating in the non-farm sector is crucial. It would also provide information for policy makers in designing policies to promote rural entrepreneurship and to transform the rural economy.

\section{Literature Review}

\subsection{Determinants of Entrepreneurship Business Incubation}

Entrepreneurship varies across economies, locations and individual characteristics. In developed economies, such as in the case of the United States are encouraging and attracting entrepreneurs by establishing entrepreneurial ecosystem and policies which help to promote entrepreneurs. Though the ecosystem is not as equally attracting as in Europe, entrepreneurship has tremendous contribution to the growth and development 
of the European economy. Variations in entrepreneurship have also been shown between rural and urban areas. Entrepreneurs in the rural areas are different prominently in terms of access to financial and support infrastructure. Rural entrepreneurs are largely factor-based rather than efficiency and innovation based. Besides, the market structure is characterised with small number of buyers in rural areas than in urban markets (Bergmann and Baumgartner, 2010). The urban entrepreneurship is well developed and given attention by policy makers rather than the rural entrepreneurial ecosystem which requires policy intervention towards the improvement of the rural entrepreneurial environment.

Gülümser et al (2009) pointed out that, although traditionally associated with agriculture, the concept of entrepreneurship in the rural areas has been a topic of continuing debate, particularly with respect to the relative importance of its sectoral (i.e. agricultural) and territorial dimensions. Rural society traditionally lacked a systematic awareness of the extent to which its man-made and natural environment was capable of innovation and competition. In addition, the rural economy is heavily dependent on self-employment and small business which are fostered through rural entrepreneurship. Rural entrepreneurship emerges as a primarily territorial activity, within which agricultural development has an important role through recognition of the "heavy reliance (of rural areas) on land as a source of livelihood" (Fieldsend et al., 2010).

Entrepreneurs in the rural areas are poor and they are entrepreneurs launched out of necessity which undermines the risk-taking capacity or willingness to take risk associated with scaling up to make a real impact on the rural economy (Lingelbach et al., 2005). A few, generally those that are relatively less poor, are opportunity entrepreneurs pursuing a profitable business, innovating and looking to grow (Lina Sonn, 2010). Rural entrepreneurs depict intermittent situation when compared along a number of dimensions: geographic (country, remoteness); demographic (gender, age, and education); production sector (agriculture, tourism, and other sectors); motivation (lifestyle, locality, job opportunities for self and family, and subsidy); and their contribution to the rural capital (natural, man-made, social, and human) (Gülümser et al., 2009).

Entrepreneurship promotion in rural areas is to create a path to do away poverty. However, entrepreneurs in rural areas lack awareness and face financial and infrastructural constraints. Financial and training and educational institutions are highly inaccessible to rural entrepreneurs constraining start-ups and business success. Entrepreneurs are constrained regarding the access to 
markets, and they are significantly dependent on middlemen who are exploiting rural entrepreneurs by making a high profit. Entrepreneurs in rural areas are also bureaucratically constrained who failed to meet legal requirements in securing a license. Their lower educational and training background has also affected their entry to business, and it has also affected acquisition and procurement of raw materials as it pushes them to end with a poor quality raw material acquisition (Gülümseret al., 2009).

Entrepreneurship in Africa is not well developed even though the creation of entrepreneurship ecosystem in the urban areas is in its development. Like entrepreneurs in developed countries, entrepreneurs in Africa have different environmental, personal and psychological features driving them to firm engagement and success in their business endeavour. However, Africa is largely agri-based, and its large population is agrarian, households are limited to farming, and a few of its population are engaged in non-growing non-farm sectors with an objective of supplementing household income and livelihood. The entrepreneurial ecosystem is underdeveloped which is constrained in terms of physical infrastructure, insufficient entrepreneurial training and education, bureaucratic and policy hurdles, and limited market size. These challenges are worse in the rural areas who are settled scattered which makes non-farm engagement difficult to realize and succeed.

Entrepreneurship is determined not only by policy environment but also by the social, demographic, cultural and psychological characteristics of individuals as entrepreneurs are persons who are involved in self-employed micro and small start-up business and deploy money, capital, labour and entrepreneurial skills to have sustainable and expanding undertaking. Hence, many writers consider entrepreneurial skill as inborn rather than acquired. However, such self-motivation, need for achievement, innovativeness, risk taking as characters describing entrepreneurs. A series of studies focus on personality and psychological characteristics and underline them as determining entrepreneurial engagement. However, contextual factors such as the social characteristics, the physical characteristics, household livelihood conditions such as shocks, and location (which vary in terms of physical infrastructure and market) are neglected as drivers to self-employing businesses particularly in poverty-stricken areas such as Ethiopia.

The study by Grilo and Thurik (2008) indicated that entrepreneurial engagement levels are determined by socioeconomic variables, perception of lack of financial support and perception of administrative complexities. Perception of administrative complexities varies across US and Europe where 
as perception of lack of financial support is no point of difference implying that entrepreneurial engagement is affected by access to financial support. Studies on non-farm enterprise identified that non-farm enterprises are low productive, supplying low-quality products and are limited to supplementing household economy. They wither when countries develop, and they are largely nongrowing small firms (Nagler \& Naude, 2014). Though they are non-growing, they are considered crucial in developing and rural economies as they promote self-employment for the fast-growing youth labour force. It has tremendous household economy contribution due to the increase in population, limited land size, and large unemployed labour force. Entrepreneurship and enterprise engagement is recognized as a strategic partner to foster employment and equitable income distribution. Non-farm sectors are then promoted as pro-poor alleviating poverty, creating employment and reducing rural-urban migration (Lanjouw \& Lanjouw 2001).

Though some scholars believe that entrepreneurial traits are innate, there is a consensus that the contextual environment has tremendous contributions to entrepreneurial start-ups and launching entrepreneurial businesses. Hence, nations establish an entrepreneurial ecosystem to foster entrepreneurship and business engagement. However, the effort to promote private sector development in agrarian dominated Africa has not resulted in significant changes owing to financial constraints, infrastructural constraints, insufficient training and education and poor entrepreneurial orientation(Jin et al., 2005; Sundaram-Stukel et al., 2006).Entrepreneurial engagement in Non-farm enterprises is promoted to transform agrarian and rural based economies(Gladwin et al., 1989; Henderson, 2002). Nevertheless, their role in many developing countries is not well recognized as they are believed to be low productive and unsustainable (Lanjouw \& Lanjouw, 2001). The central theme of the development effort in many developing countries has been increasing agricultural yield and productivity which limits the growth of the nation and moving attention to rethink on the importance of the non-farm sector is believed to be critical (Proctor, 2014). In these agriculturally dominant countries, implementing non-farm oriented policies will foster social transformation as they improve firm engagement which will result in employment creation and income growth at household, local and national level (Henderson, 2002; Mwabu and Thorbecke, 2004).

Entrepreneurship and firm engagement depend on several factors including individual traits and entrepreneurial ecosystem(Dary \& Kuunibe, 2012;Nagler \& Naude, 2014; Stathopoulou et al., 2004). Individual socio-demographic and psychological traits are considered drive them to exploit their capacity in 
creating and succeeding in a business endeavour. The age, sex, marital status, economic conditions determine their risk taking behaviour and creation and launching of undertakings (Dugassa, 2012). The entrepreneurship ecosystem consisting of actors such as government, non-government, professional associations and education and training institutions determine start-ups and success in the business. Moreover, credit access, technology support, market access, and networking ascertain the success of entrepreneurs (Osondu et al, 2014; Nagler \& Naude, 2014; Stathopoulou et al., 2004; Trienekens, 2011).

Nagler and Naude (2014) identified those individual capabilities, household characteristics and institutional factors driving households' engagement in the non-farm enterprise. The role of the sector is no more than risk diversifying, but it plays a little role in creating wage employment opportunities and fostering effective rural urban migration. Nevertheless, the study by Rijers \& Sederon (2013) found that neither shock nor risk affects the propensity of running Non-Farm Enterprises(NFE) rather they hamper non-farm enterprise development by repressing investment and leading households' to less capital intensive activities.

Despite the controversies on the impact of and determinants to non-farm engagement, efforts have been provided to enhance entrepreneurship and business development by government and non-government organisations. Nevertheless, the support services in the rural areas are limited to increase agricultural yield. Private sector participation in the countryside remains small. Support was prominently provided via the rural development offices and agricultural cooperatives (Abebaw and Haile, 2013; Abebe, 2015). Marketing cooperatives tend to offer secure markets thereby improving market orientation and market driven agricultural investment (Abebe, 2015; Abebe and Jimi, 2015). Private sectors in input supply, value added activities and marketing of agricultural produce are not yet mature to bring about developed rural enterprises in the country. Nevertheless, little has been done on previous studies regarding cooperatives, access to rural development offices whether they determine households' engagement in the non-farm sector. Moreover, the income effect to rural households who engaged in the non-farm sector is not well addressed. This study there for is to address the determinants enterprise engagement in Ethiopia considering LSMS data of the World Bank.

This study explores the determinants of smallholder farming households' participation in NFE in Rural Ethiopia as a strategy for livelihood diversification. It identifies the significant determinants using logit model. The study extends its objective by assessing the effect of non-farm enterprise sector on household income and livelihood. Data for the analysis was captured from 
four districts located in Northern Ethiopia. The study will benefit policy makers by identifying the determinants and understand the significance of NFE for rural household livelihood diversification strategies. It helps policy makers to design strategies to enhance households' involvement in business (NFE) to facilitate rural transformation in sub-Saharan Africa and change the socioeconomic conditions of rural communities.

Non-farm enterprise studies tried to analyse with a limited context dealing less on variations in regional endowments, socio-cultural such as marital status and religion of the actors, educational engagement and household shocks (Dary \& Kuunibe, 2012; Nagler \& Naude, 2014). Moreover, the previous studies largely concentrate on demographic and individual characteristics. Hence, this paper is designed to fill this gap by taking the wider Ethiopian context to accommodate more sample households from the nine regions of the nation. Therefore, this study aims at exploring the determinants of non-farm engagement in rural and urban Ethiopia. More specifically, the study is to confirm whether socioeconomic characteristics imply variations in non-farm engagement in rural and urban households in Ethiopia. More specifically, it considers such variables as marital status, ethnicity, access to credit; sex, family size, age, education, and religion affect in driving households to engage in the non-farm sector. The study helps policy makers to shape intervention programs to stimulate and facilitate sustainability in non-farm enterprises.

\subsection{The Ethiopian Context}

Agriculture is the main feature of Ethiopia, and more than $80 \%$ of its people rely on agriculture (IFAD 2011). State land ownership offers not more than a hectare of land to a household leading mainly to subsistence agriculture. Rural development policies are based mainly on expanding agricultural productivity through input and technology supply and extension services provision (Gebregziabher, 2015). The rural development policy relies on integrated household package systems allowing households to engage in a variety of packages to sustain a household livelihood. Tremendous public spending has been made in agriculture to improve productivity and food security at household level through its integrated household package program (Felo et al 2010). Investment in agriculture has been intensified as it is a major source of employment for the fast growing young labour force as in many sub-Saharan African countries (Salami et al., 2010; IFAD, 2011; Gollin, 2014; Jayne et al., 2014).

EJBE Vol. 6 No. 2/2016

Page 243 
The focus of the rural development effort has been on promoting access to rural technology, inputs and extension services (Gebregziabher, 2015). The dire poverty situation drives development policy makers to center on increasing agricultural yield. Policies on non-farm enterprises (NFEs) do not go hand in hand slowing the development efforts. The unemployment and poverty conditions remain a challenge in the developing countries. The role played by non-farm enterprise sectors is undermined as low productive, producing low quality and not sustainable (Nagler \& Naude, 2014). NFEs would foster employment, improve income and reduce poverty (Mwabu and Thorbecke, 2004). NFEs fail to be well integrated into the development policies to diversify household livelihood strategies (Lanjouw \& Lanjouw 2001; Reardon et al., 2006; Proctor, 2014; Nagler \& Naude, 2014).

Smallholder agriculture features Ethiopia, where agricultural production is low, with a little farm, produces left to the market affecting market orientation and participation (Abebe, 2015; Abebe and Adesina, 2015). Though farming is dominant in the country, households participate in a variety of micro and small enterprises as main and income diversifying strategies in rural and urban areas. Participation in non-farm engagement is largely at small scale level to use it as alternative income source with a little intention to expand. Traditionally, during the Imperial period (1939-1974), the landed aristocracy and the tenants (the majority of peasants) constitute the major socio-economic agents; and participation in non-farm enterprise was not regarded as an occupation under the individuals' choice (Alemayehu, 2005). During that regime, the country is dominated by agriculture and enterprise engagement was not promoted by the society which in turn eroded the launching of enterprises and technical innovation. To worsen the situation, during the socialist Derg regime (19741991), there was repression of market oriented policy and declaration of command economy which limited investment capital in the country. The command economic policy of the government constrained expansion of private businesses although there was support largely for micro and small-scale enterprises that engage in handicrafts particularly in urban areas. Corporations like insurance companies, banking, wholesale and retail businesses were nationalized which threatened business formation and entrepreneurial development in the country. The regime also centralized the distribution of agricultural products via Agricultural Marketing Corporation (AMC) which narrowed the market channel options for farmers. Market forces were officially repressed due to the socialist ideology (Alemayehu, 2005).

The current government came to power in 1991 and declared market economy. It removed capital and property restrictions(Alemayehu, 2005).Quota 
requirements for farmers were terminated, and farmers are left free to market their produce to any market although the market was underdeveloped and inefficient. Proclamations that support private ownership and enhancement of business are in place. More recently, the government of Ethiopia developed the Growth and Transformation Plan (GTP I\&II) to guide the nation's efforts for growth, employment creation and transforming Ethiopia from an agrarian society into a modern and industrialized country (World Bank, 2015). Expanding microcredit and business development services have been underway.

The focus of the policy has been on agriculture development led industrialization (ADLI) which rely on creating access to rural technology, inputs and extension services. The urban and rural poverty conditions stimulate policy makers to strengthen microenterprises and improve agricultural productivity at household level. Policies on non-farm enterprises (NFEs) however do not go hand in hand slowing the development efforts. The unemployment and poverty conditions remain a challenge in the country. The role played by non-farm enterprise sectors is undermined as low productive, producing low quality and not sustainable (Nagler \& Naude, 2014). NFEs would foster employment, improve income and reduce poverty (Mwabu and Thorbecke 2004). NFEs fail to be well integrated in the development policies to diversify household livelihood strategies (Lanjouw \& Lanjouw, 2001; Reardon et al., 2006; Proctor, 2014; Nagler \& Naude, 2014).increase in population and young labor force has led to large unemployed labor demanding policy makers to consider NFEs as strategic sector to create opportunities. The poverty situation and the scarce land resources also push policy makers to consider NFEs as strategies to ameliorate poverty and offer sources of income for households. NFEs are believed to be pro-poor facilitating poverty reduction, employment and slowing rural-urban migration (Lanjouw \& Lanjouw, 2001).

Non-farm enterprises need entrepreneurial skills so as to start, grow and sustain the enterprises. Though the NFEs are largely micro-enterprise and informal requiring small capital, skills to run, manage, and expand the firm are crucial. The entrepreneurial ecosystem mainly focuses on formal (small, medium and large) firms. Policy intervention in promoting NFE entrepreneurship is negligible despite the fact that entrepreneurship skill is acquired. It is commonly applied in both developed and developing countries to develop entrepreneurship skills and those who trained and educated with entrepreneurial skills are found more involved and succeed in the sector (Dugassa, 2012). For this, nations create institutions to offer support and 
promotional services to encourage entrepreneurship and business development. However, the effort to promote private sector development in rural Africa has not resulted in significant changes owing to poor road and communication infrastructure, weak institutions, low levels of education and skill in entrepreneurship and business development, poor capital accumulation (poor saving culture) and lack of finance, and lack of strong commitment from the private sector (Jin et al., 2005; Sundaram-Stukel et al., 2006). Non-farm engagement in Ethiopia is reported to be $30 \%$ ( Nagler and Naude (2014) indicates that 30.54 per cent of the sampled rural households in the national survey participates in NFE implying the popularity of the sector. The paper is organized as follows: the next section reviews the literature and builds the framework of the study. The third section discusses the research methods adopted in the study. The fourth section presents the data and a discussion of the findings. The final section presents the conclusions and policy implications of the findings.

\section{Methodology}

\subsection{Data}

Ethiopia is Africa's oldest independent country and it is second largest populous country next to Nigeria. It has a unique cultural heritage, being the home of the Ethiopian Orthodox Church - one of the oldest Christian churches - and a monarchy that ended only in the coup of 1974 . The country is served as a symbol of African independence throughout the colonial period, and was a founder member of the United Nations. It is the African base for many international organisations. The country has nine regional states and administrative cities established with the ethnic-based federal system.

The country is part of the Sub-Saharan African region. It is a low-income country with a population of nearly 100 million. The GNI per capita is USD 550. It is one of the fastest growing non-oil economies in Africa; and yet the country strongly depends on agriculture which contributes $44 \%$ to the GDP. Ethiopia is one of the poorest states in Africa but it has demonstrated rapid economic growth since the end of the civil war in 1991. Agriculture is the dominant sector in the economy which relies on rainfall. It is one of Africa's leading coffee producers.

This study is based on the data captured by LSMS survey of the World Bank. All regions in Ethiopia are covered by the survey. The sample size is 5262 (3323 rural and 1939 urban households). Data analysis involves descriptive 
statistics and Tobit model has been employed to identify significant determinants.

\subsection{Empirical Model}

Diversified business activities in which households engage in entrepreneurial businesses is considered for the analysis. Households in Ethiopia participate in a variety of enterprise activities such as non-agricultural, agricultural, services, and retailing. Households' involvement in these diversified sectors to generate income and sustain their household believed to demonstrate their entrepreneurial orientation which leads them to engage in enterprise sectors. We developed the enterprise engagement index as dependent variable which is a function of aggregate socioeconomic characteristics (household heads characteristics such as age, sex, and family size), marital status, location, regional endowments, credit access and education.

The enterprise engagement index is the level of business involvement with value between 0 and $1(0 \%-100 \%)$ which is calculated from the eight business activities urban and rural households are engaged in. the eight business activities are Non-agricultural business, Agricultural petty trade, trading business, Charcoal and firewood selling, professional service, taxi service, As the households are engaged in one or more business sectors, bar and restaurant and Other non-farm business the enterprise engagement index $\left(\mathrm{E}_{\mathrm{i}}\right)$ is generated from the average of the households participation in the eight sectors identified and it ranges between 0 and 1 . More specifically,

$$
E_{i}=\frac{1}{8 \sum_{i=1}^{8} D},
$$

Where, $\mathrm{D}$ is the diversified business activities that are dummy variables: $1=y e s$, if the household participates and $0=$ otherwise).As the index is limited dependent variable which is between 0 and 1 , we prefer to employ the Tobit model with the following specification(Tobin, 1958; Carson and Sun, 2007):

$$
Y_{i}=\left\{\begin{array}{c}
E_{i}^{*} \text { if } E_{i}^{*}>0 \\
0 \text { if } E_{i}^{*} \leq 0
\end{array}\right\}
$$

Where $E_{i}^{*}$ is a latent variable just as in a linear model and it is specified as:

$$
Y_{i}^{*}=\beta_{0}+X_{i} \beta+\varepsilon_{i} .
$$

Where $Y_{i}^{*}$ is an enterprise engagement index, $\beta_{0}$ is the intercept, $\beta$ is unknown parameter coefficient and $\mathrm{X}$ is observed $1 \mathrm{X} \mathrm{k}$ explanatory variables and $\varepsilon_{i}$ is the error term. Maximum likelihood model is used to estimate the parameter coefficients. Same model is applied for both rural and urban entrepreneurs. 


\section{Results and Discussion}

\subsection{Descriptive Statistics}

The rural entrepreneurs are predominantly engaged in charcoal and fuel wood selling which is largely natural resource dependent. Their involvement in this subsector adversely affects the vegetation cover in the rural parts aggravating deforestation and degradation. It also negatively affects agricultural productivity. The rural entrepreneurs dominate almost in all sectors except charcoal and fuel wood selling and agricultural petty trade (Table 1).

Table 1: Households' non-farm sector engagement

\begin{tabular}{llclc}
\hline \multirow{2}{*}{ Variable } & \multicolumn{2}{c}{ Rural households } & \multicolumn{2}{c}{ Urban households } \\
\cline { 2 - 5 } & Mean & Std. error. & \multicolumn{1}{l}{ Mean } & Std. error. \\
\hline Non-agricultural business & .073 & .004 & $.183^{* * *}$ & .006 \\
Agricultural petty trade & .071 & .004 & .073 & .005 \\
Trading business & .045 & .004 & $.079^{* * *}$ & .006 \\
Charcoal and firewood selling & .037 & .003 & $.013^{* * *}$ & .003 \\
Professional service & .001 & .002 & $.005^{* * *}$ & .001 \\
Taxi services & .005 & .001 & $.023^{* * *}$ & .003 \\
Bar and restaurant & .002 & .003 & $.020^{* * *}$ & .001 \\
Other non-farm business & .048 & .004 & $.072^{* * *}$ & .006 \\
\hline Number of observations & 3323 & & 1939 & \\
\hline \multicolumn{2}{c}{$* * *$ Significant at 0.01 level of significance } & & &
\end{tabular}

Relatively better paying subsectors are dominated by the rural urban sectors implying that the number of non-farm enterprises in the rural Ethiopia is relatively lower in contrast to their number in the urban areas. Rural entrepreneurs are largely natural resource dependent relative to the urban entrepreneurs who are operating in the service sector dominantly. The descriptive result reveals that the number of non-farm enterprises is lower (Table 1) which requires policy makers to establish and strengthen the rural entrepreneurship ecosystem so as to promote non-farm engagement in the rural Ethiopia such that households livelihood will be improved and strengthened.

\subsection{Empirical Model Results}

The model result on Table 2 indicates the independent variables determining non-farm engagement among the sample households in the rural and urban Ethiopia. Demographic variables, resource access, ethnicity, religion, marital status and educational types are captured in this study to identify significant variables driving rural and urban households to non-farm enterprises. Separate 
analysis was conducted so as to assess if there is variations in driving factors for rural households and urban households. The involvement in non-farm enterprise is considered as households' entrepreneurial move to selfemployment which largely characterise life style entrepreneurship who are working to generate income to finance household livelihood than investing on the growth of the firm.

The result indicated that sex and age are significant drivers for urban households implying that male headed urban households are more in the nonfarm enterprise sector. In addition, young household heads largely involved in urban non-farm enterprises. As the age increases, the household non-farm engagement also increases. However, non-farm engagement declines after the age of 58 and then the tendency to engage in non-farm business decreases implying that entrepreneurial engagement is more of the adult household heads. These two variables were found insignificant for the rural households. However, larger household size in the rural and urban households drives them to engage more in non-farm sectors implying that more labour endowment leads to non-farm enterprise engagement. It also drives larger households to participate in NFE sectors to generate more income to sustain the household. Resources access such as access to finance in terms of credit is found playing crucial role in encouraging urban households' non-farm engagement. The empirical result indicates positive association between credit taken and engagement in non-farm businesses.

Household profiles regarding the occurrence of shock were also controlled in terms of illness, drought, loss of jobs and flood. The occurrence of shock in terms of illness and drought drives rural households to NFE. However, no significant association was found between shocks and NFE engagement for urban households. Illness is found positively influencing rural households to engage in NFE. However, occurrence of drought is found adversely affecting households non-farm engagement as its effect is to the community and it also erodes the purchasing power of the community leaving the market with no capable buyers and leading the community to rely on aid rather than encouraging them to engage in non-farm sectors. In addition, it perhaps depletes the capital household would probably use to start NFE.

The impact of ethnicity is also controlled by taking respondents in the nine regions of Ethiopia that are constituted in terms of ethnic based federalism. Accordingly, some ethnic groups are found significantly participating in nonfarm sectors more than the others in the rural areas. These regional states include Tigray, Benishangul Gumuz, Harari and Dire Dawa. Urban households in Tigray, Afar, Amhara, Oromia, Southern Nations, Nationalities and Peoples (SNNP) and Gambella were involved in NFE. This implies that the 
participation of more regional states (ethnic based states) in the urban areas than rural areas.

Households' marital status is found affecting households non-fam engagement. The model result indicated that those who are married polygamy and divorced in the rural areas were found drivers to engage in NFE. Where as in those never married in the urban areas are negatively associated with NFE and like the rural households, divorce is found positively associated with NFE engagement. If they are not married, they may also be resource constrained deterring their courage and engagement in the non-farm sector. However, those who are divorced are found largely involved in the non-farm sector which may imply that decision making liberty may attract households to non-farm engagement. Divorce may also result in reduction of household income leading households to engage in non-farm sector as source of income for the households' livelihood. In terms of religion, all the available religions were controlled and their contribution is more for the rural households. Orthodox believers and those who believe in traditional religions and pagan were found driving households to NFE.

In terms of education type, primary education is driving rural households to engage in rural households to NFE. Those, who are illiterate and with basic information in the urban areas, are more involved in NFE. This implies those with lower or no educational level is more involved in NFEs. Accordingly, low educational level is found driving households to non-farm sectors. This may be due to the reason that the non-farm sectors identified are less sophisticated and they are easy to launch. They require less education. This may also imply that many of the non-farm sectors are to diversify household livelihood strategies as sources of income than growth of the firm by making further expansion investment in the sector. 
Entrepreneurship Drivers in the Non-farming Sector

Table 2: Dépendent variable: Enterprise Engagement Index (Tobit Model)

\begin{tabular}{|c|c|c|c|c|c|c|c|c|}
\hline \multirow{2}{*}{$\begin{array}{l}\text { Independent } \\
\text { variables }\end{array}$} & \multicolumn{4}{|c|}{ Rural households } & \multicolumn{4}{|c|}{ Urban households } \\
\hline & Coefficient & $\begin{array}{l}\text { Std. } \\
\text { Err. }\end{array}$ & $\mathrm{t}$ & $P>t$ & Coefficient & $\begin{array}{l}\text { Std. } \\
\text { Err. }\end{array}$ & $\mathrm{t}$ & $\mathrm{P}>\mathrm{t}$ \\
\hline Sex_HHH & -0.007 & 0.016 & -0.410 & 0.682 & $0.026^{\mathrm{b}}$ & 0.012 & 2.190 & 0.029 \\
\hline Age_HHH & 0.000 & 0.002 & -0.160 & 0.871 & $0.007^{\mathrm{a}}$ & 0.002 & 3.800 & 0.000 \\
\hline Age_HH ${ }^{2}$ & 0.000 & 0.000 & -0.880 & 0.380 & $0.000^{\mathrm{a}}$ & -0.000 & -4.180 & 0.000 \\
\hline HH_Size & $0.010^{\mathrm{a}}$ & 0.002 & 4.170 & 0.000 & $0.016^{\mathrm{a}}$ & 0.002 & 6.980 & 0.000 \\
\hline Credit_taken & 0.011 & 0.011 & 1.060 & 0.289 & $0.047^{\mathrm{a}}$ & 0.010 & 4.660 & 0.000 \\
\hline Shock_death & -0.071 & 0.044 & -1.610 & 0.108 & -0.011 & 0.034 & -0.330 & 0.740 \\
\hline Shock_flood & -0.011 & 0.033 & -0.350 & 0.730 & -0.072 & 0.093 & -0.770 & 0.439 \\
\hline Shock_ill & $0.039^{\mathrm{a}}$ & 0.015 & 2.590 & 0.010 & 0.008 & 0.015 & 0.540 & 0.586 \\
\hline Shock_Jobloss & -0.015 & 0.055 & -0.280 & 0.781 & 0.032 & 0.026 & 1.240 & 0.215 \\
\hline Shock_drought & $-0.039^{b}$ & 0.018 & -2.190 & 0.029 & -0.017 & 0.124 & -0.140 & 0.891 \\
\hline Tigray & $-0.060^{\mathrm{b}}$ & 0.029 & -2.080 & 0.037 & $0.080^{\mathrm{a}}$ & 0.026 & 3.070 & 0.002 \\
\hline Afar & -0.018 & 0.035 & -0.510 & 0.607 & $0.128^{\mathrm{a}}$ & 0.037 & 3.460 & 0.001 \\
\hline Amhara & -0.040 & 0.026 & -1.550 & 0.122 & $0.096^{\mathrm{a}}$ & 0.025 & 3.760 & 0.000 \\
\hline Oromia & -0.002 & 0.025 & -0.080 & 0.933 & $0.057^{\mathrm{b}}$ & 0.025 & 2.290 & 0.022 \\
\hline Benishangul & $0.125^{\mathrm{a}}$ & 0.030 & 4.100 & 0.000 & 0.073 & 0.054 & 1.360 & 0.174 \\
\hline SNNP & 0.032 & 0.026 & 1.240 & 0.215 & $0.091^{\mathrm{a}}$ & 0.026 & 3.500 & 0.000 \\
\hline Gambela & 0.047 & 0.035 & 1.350 & 0.177 & $0.124^{\mathrm{a}}$ & 0.042 & 2.960 & 0.003 \\
\hline Harari & $0.096^{\mathrm{a}}$ & 0.030 & 3.140 & 0.002 & -0.001 & 0.037 & -0.030 & 0.978 \\
\hline Addis Ababa & (omitted) & & & & -0.015 & 0.026 & -0.570 & 0.566 \\
\hline Dire Dawa & $0.182^{\mathrm{a}}$ & 0.029 & 6.320 & 0.000 & 0.035 & 0.030 & 1.180 & 0.238 \\
\hline Somali & (omitted) & & & & (omitted) & & & \\
\hline Never married & -0.039 & 0.032 & -1.210 & 0.226 & $-0.029^{\mathrm{c}}$ & 0.015 & -1.880 & 0.060 \\
\hline Married polygamy & $0.037^{\mathrm{c}}$ & 0.023 & 1.640 & 0.100 & -0.010 & 0.056 & -0.180 & 0.856 \\
\hline Divorced & $0.045^{\mathrm{c}}$ & 0.023 & 1.900 & 0.058 & $0.061^{\mathrm{a}}$ & 0.016 & 3.740 & 0.000 \\
\hline Separated & 0.052 & 0.040 & 1.300 & 0.192 & 0.017 & 0.028 & 0.610 & 0.543 \\
\hline Widowed & 0.006 & 0.021 & 0.270 & 0.784 & 0.003 & 0.017 & 0.190 & 0.849 \\
\hline $\begin{array}{l}\text { Married } \\
\text { monogamy }\end{array}$ & (omitted) & & & & (omitted) & & & \\
\hline Orthodox & $0.132^{\mathrm{b}}$ & 0.062 & 2.120 & 0.034 & 0.004 & 0.046 & 0.080 & 0.937 \\
\hline Protestant & 0.083 & 0.062 & 1.340 & 0.180 & -0.019 & 0.047 & -0.410 & 0.684 \\
\hline Muslim & 0.076 & 0.063 & 1.220 & 0.222 & 0.024 & 0.047 & 0.510 & 0.608 \\
\hline Others & $0.129^{\mathrm{c}}$ & 0.069 & 1.880 & 0.060 & 0.056 & 0.080 & 0.700 & 0.487 \\
\hline Wakifata & 0.011 & 0.089 & 0.130 & 0.898 & -0.945 & & & . \\
\hline Catholic & (omitted) & & & & (omitted) & & & \\
\hline Illiterate & 0.098 & 0.069 & 1.400 & 0.161 & $0.064^{\mathrm{a}}$ & 0.018 & 3.580 & 0.000 \\
\hline Basic_ifoe $\sim c$ & 0.107 & 0.071 & 1.500 & 0.133 & $0.070^{\mathrm{a}}$ & 0.021 & 3.370 & 0.001 \\
\hline Primary_1s c & $0.126^{\mathrm{c}}$ & 0.076 & 1.670 & 0.096 & 0.036 & 0.025 & 1.400 & 0.161 \\
\hline Primary_2n c & $0.129^{\mathrm{c}}$ & 0.077 & 1.680 & 0.094 & 0.030 & 0.021 & 1.440 & 0.149 \\
\hline Secondary, above & (omitted) & & & & (omitted) & & & \\
\hline Constant & $-0.341^{\mathrm{a}}$ & 0.106 & -3.220 & 0.001 & $-0.368^{a}$ & 0.068 & -5.450 & 0.000 \\
\hline Sigma & 0.198 & 0.006 & & & 0.153 & 0.005 & & \\
\hline $\begin{array}{l}\text { No. of } \\
\text { observations }\end{array}$ & 3278 & & & & 1923 & & & \\
\hline Left censored obs. & 2492 & & & & 1163 & & & \\
\hline Uncensored obs. & 786 & & & & 760 & & & \\
\hline LR $\operatorname{chi} 2($ & $229.97^{\mathrm{a}}$ & & & & $344.60^{\mathrm{a}}$ & & & \\
\hline Pseudo R2 & 11.84 & & & & 0.371 & & & \\
\hline
\end{tabular}

EJBE Vol. 6 No. 2/2016 
Households who collected credit and of whom the highest $(26.70 \%)$ were to start a business and 58.04 per cent acquired credit from microfinance institutions. Nevertheless, $68.26 \%$ did not attempt to take credit as they did not want to be indebted, having enough from their own farm and for fear of inability to pay as the three main reasons.

The welfare effect of non-farm sector engagement is also assessed in terms of their weekly food consumption and non-food expenditure. Accordingly, four basic types of food (injera, meat, milk and vegetable) were considered and the number of days households consume in a week is used to analyse the effect of non-farm sector engagement. The simple t-test result indicates that the number of days households participating in non-farm sector in consuming injera, meat and vegetable is significantly different from households who did not engage in the non-farm sector. The result indicates that non-farm engaging households consume less of injera, meat, and vegetable in contrast to those who did not engage in the sector. This implies that, the households are still live in poverty and the sector does not do beyond feeding households.

\section{Conclusion and Implications}

Non-farm enterprises are promoted in developing countries as they are largely agrarian and natural resources dependent. The sector is to supply households with alternative income generating scheme, employment creation, and it is also an important strategy to minimize rural-urban migration. Nevertheless, the sector remains subsistence which contains activities that do not grow and contributing less to local and national economy. Considerable number of rural and urban households are engaged in the sector implying how crucial the sector is to the poor households. Regional (ethnic) variations are observed and small number of households are engaged in Addis Ababa and Ethiopian Somali regional states. In the emerging regional states such as Benishangul Gumuz, large numbers of households were found largely involved in the non-farm sectors.

Non-farm enterprises are found to be driven by age, family size and access to credit. This implies that the young in various locations of the country are found largely operating in non-farm sectors. This may be due to the fact that in rural and urban areas, the degree of young unemployment is high and they are driven to engage in the sector as the source of income by creating selfemployment. Households with large household size are also found driven to non-farm enterprises as they are endowed with large labour force; household members are also operating in the sector to finance their household expenditure. Those households who took credit are driven to non-farm business 
sectors and more than 26 took the loan for business implying that access to credit has positive contribution to non-farm sector engagement.

Divorced households are driven to non-farm sector engagement which may entail us two basic implications. The first implication is that the loss of income resulted from divorce drive households to engage in the sector so as to finance the households' expenditure. The second likely reason may be the decisionmaking discretion households exercise may drive them to engage in the sector. Households with lower educational background are found highly driven in the non-farm sector implying that the sector is dominated by the less educated once having an effect on its sustainability and growth of the sector. Secondary and college education were found insignificant for non-farm sector engagement. It is indispensable for policy makers to understand the characteristics of the households in the sector and tune intervention strategies to these households who are divorced, illiterate, with large family size. The finding entails us that the poor households are still involved in the sector as it creates self-employment opportunity. The entrepreneurship ecosystem for the non-farm sector largely contains credit provision, training on simple bookkeeping, on how to expand and shift business to efficiency and innovation based rather than relying largely on factor and natural resources based. 
Entrepreneurship Drivers in the Non-farming Sector

\section{References}

Abebaw, D. G.M. Haile, 2013.The impact of cooperatives on agricultural technology adoption.Food Policy 38:82-91.

Abebe, Ejigu Alemu, Jimi O., Adesina. 2015. Effects of co-operatives and contracts on rural income and production in the dairy supply chains: Evidence from Northern Ethiopia. African Journal of Agricultural and Resource Economics 10 (4):312-327.

Abebe, Ejigu Alemu, 2015. Technology and market access via contracts and cooperatives for smallholders: Evidence from honey producers in Ethiopia, African Journal of Science, Technology, Innovation and Development 7(6):420-428.

Alemayehu, G. 2007.The political economy of growth in Ethiopia. In Benno N., S. O'Connell, R. Bates, P. Collier and C. Soludo (eds)The Political Economy of Economic Growth in Africa, 1960-2000,.Cambridge University Press.

Aliaga-Isla, R.,A. Rialp. 2013. Systematic Review of Immigrant Entrepreneurship Literature: Previous Findings and Ways Forward. Entrepreneurship \& Regional Development 25 (9-10): 819-844.

Gülümser, A., Nijkamp, P., Baycan-Levent,T., Brons, B. 2009. Embeddedness of Entrepreneurs in Rural Areas: A Comparative Rough Set Data Analysis. Tinbergen Institute Discussion Paper, No. TI 2009-058/3. https://papers.tinbergen.nl/09058.pdf (Retrieved: 12 January 2017).

Barkema, A., M. Drabescott. 2000. How Rural America sees its Future, The Main Street Economist, Federal Reserve Bank of Kansas City, Kansas City.

Brownhilder, Ngek. 2012.The impact of entrepreneurial characteristics and business practices on the long term survival of small and medium enterprises, Republic of South Africa.

Cabinet Office.1999. Rural Economies, Performance and Innovation Unit Report - December, Cabinet Office, London.

Carson, R., Y. Sun. 2007.The Tobit model with a non-zero threshold.Econometrics Journal 10: 488-502.

Chris, Reij, Ann Waters-Bayer. 2001. Farmer Innovation in Africa: A source of inspiration for agricultural development. Earthscan Publication Ltd., London.

Christian, H. and Johannes, M. 2017. Does entrepreneurship pay for women and immigrants? A 30 year assessment of the socio-economic impact of entrepreneurial activity in Germany, Entrepreneurship \& Regional Development, 29:5-6, 517-543. 
Spielman, D., Davis, K.,Negash, M., Ayele, G. 2010.Rural innovation systems and networks: findings from a study of Ethiopian smallholders.

Davis, J. \& Bezemer, D. 2004. The Development of the Rural Non-Farm Economy in Developing Countries and Transition Economies: Key Emerging and Conceptual Issues. World Development 29(3): 481-496.

Drucker, P. 1970. Entrepreneurship in Business Enterprise.Journal of Business Policy Vol.1.

Drucker, P. 1984. Innovation and Entrepreneurship.Practice and Principles. Harper Collins Publisher, Pty. Ltd. 25 Ryde Road, Pymble, NSW 2073, Australia.

Dugassa, T.G. 2012.Impact of entrepreneurship education on entrepreneurial intention of business and engineering students in Ethiopia.African Journal of Economic and Management Studies 3(2): 258-277.

Fayolle, A. 2007. Entrepreneurship and new value creation: the dynamic of the entrepreneurial process. Cambridge University Press. The Edinburgh Building, Cambridge, CB2 2RU, UK.

Francesconi, G.N., N. Heerink\&M. D'Haese. 2010. Evolution and challenges of dairy supply chains: evidence from supermarkets, industries and consumers in Ethiopia. Food Policy 35(1):60-68.

Gebregziabher, K.G. 2015.The impact of agricultural extension on households' welfare in Ethiopia.International Journal of Social Economics 42(8): 733-748.

Gebremedhin B., M. Jaleta. 2012. Market Orientation and Market Participation of Smallholders in Ethiopia: Implications for Commercial Transformation. Selected Paper prepared for presentation at the International Association of Agricultural Economists (IAAE) Triennial Conference, Foz do lguacu, Brazil, 18-24 August, 2012. Pp 26.

Gebremedhin, B., M. Jaleta \& D. Hoekstra. 2009.Smallholders, institutional services and commercial transformation in Ethiopia. Agricultural Economics 40:773-787.

Gladwin, C.H., B. F. Long, E.M. Babb, L.J. Beaulieu, A. Moseley, D. Mulkey, D.J. Zimet. 1989. "Rural Entrepreneurship: One Key to rural Revitalization". American Journal of Agricultural Economics December 1305-1314.

Gollin, D. 2014. Smallholder agriculture in Africa: An overview and implications for policy. IIED Working Paper. IIED, London. Pp.24.

Guerrero, M., Pena-Legazkue, I. 2012. Entrepreneurial activity and regional development: an introduction to this special issue. Investigaciones Regionales 26: 5-15. 
Hardeep Kaur, Anupama Bains.2013. Understanding The Concept Of Entrepreneur Competency: Journal of Business Management \& Social Sciences Research Volume 2, No.11, pp-31-33.

Harper, D. 2003.Foundations of entrepreneurship and economic development. Routledge, 11 New Fetter Lane, London EC4P 4EE.

Hjorth, D. 2013.Public Entrepreneurship: Desiring Social Change, Creating Sociality.Entrepreneurship and Regional Development 25 (1-2): 3451.

Ingstrup, MB., Christensen, PR. 2017. Transformation of cluster specialization in the wake of globalization.Entrepreneurship \& Regional Development, 29 (5-6): 500-516.

International Fund for Agricultural Development (IFAD). 2011. Rural Poverty Report. Rome, Italy.

J. Robert Baum, Edwin A. Locke. 2004. The Relationship of Entrepreneurial Traits, Skill, and Motivation to Subsequent Venture Growth: University of Maryland.

Jayne, T.S., F. Meyer, L. N. Traub. 2014. Africa's Evolving Food Systems: Drivers of change and the scope for influencing them. IIED Working Paper. IIED, London. Pp.24.

Karen, L., Williams Middleton. 2010. Developing Entrepreneurial Behavior, Gothenburg, Sweden.

Khandker, R., B. Gayatri \& A. Hussain. 2010. Handbook on impact evaluation: quantitative methods and practices. The World Bank, Washington D.C.

Korsgaard, S., M. Sabine. 2015.Rural entrepreneurship or entrepreneurship in the rural - between place and space. International Journal of Entrepreneurial Behaviour \& Research 21(1):5-26.

Lanjouw, J.O., Lanjouw, P. 2001. The Rural Non-Farm Sector: Issues and Evidence from Developing Countries. Agricultural Economics 26: 1-23.

Lechner, M. 2002. Program heterogeneity and propensity score matching: an application to the evaluation of active labour market policies. The Review of Economics and Statistics 84(2): 205-220.

Maertens, M.,JFM.Swinnen. 2009.Trade, standards and poverty: evidence from Senegal. World Development 37(1): 161-178.

Marlow, S.,J. Swail. 2014. Gender, Risk and Finance: Why Can't a Woman Be More Like a Man? Entrepreneurship \& Regional Development 26 (12): 80-96.

Martijn P. Driessen, Peter S. Zwart. 2000. The Entrepreneur Scan Measuring Characteristics and Traits of Entrepreneurs. 
Ménard, C. 2007.Cooperatives: Hierarchies or Hybrids? In: Vertical Markets and Cooperative Hierarchies: The Role of Cooperatives in the AgriFood Industry. In Case, K. Karantininis and J. Nilsson (eds.), Dordrecht: Springer, pp. 1-17.

Mwabu G., Thorbecke E. 2004. Rural Development, Growth and Poverty in Africa.Journal of African Economies 13 (AERC Supplement 1):i16-i65.

Nagler, P., Naudé, W. 2014. No-Farm Enterprises in Rural Africa: New Empirical Evidence. Policy Research Working Paper 7066. Washington, DC: World Bank. Pp. 52.

Nagler, P., Naudé, W. 2014. Non-Farm Entrepreneurship in Rural Africa: Patterns and Determinants. IZA DP No 8008. Bonn: IZA.

North, D., D. Smallbone.1996. Small business development in remote rural areas: the example of mature manufacturing firms in northern England", Journal of Rural Studies, Vol. 12, No. 2, Elsevier, pp. 151167.

OECD.2003. The Development of Broadband Access in Rural and Remote Areas, Working Party on Telecommunication and Information Service Policies, Directorate for Science, Technology and Industry, Committee for Information, Computer and Communications Policy, Paris.

Onuoha, G. 2007. Entrepreneurship, AIST International Journal 10:20-32.

Oya, C. 2012.Contract farming in Sub-Saharan Africa: A survey of approaches, Debates and Issues. Journal of Agrarian Change 12:1-33.

Parker, SC. 2004.The economics of self-employment and entrepreneurship.Cambridge University Press. The Edinburgh Building, Cambridge, CB2 2RU, UK.

Reardon, T., J. Berdegué, C.B. Barrett, K. Stamoulis. 2006. Household Income Diversification into Rural Nonfarm Activities in Steven Haggblade, Peter Hazell and Thomas Reardon, editors. Transforming the Rural Nonfarm Economy, Baltimore: Johns Hopkins University Press.

Reardon, T., Berdegue, J., Barrett, C.,Stamoulis, K. 2006.Household Income Diversification into Rural Non-Farm Activities. Baltimore: Johns Hopkins University Press.

Rijkers, B., Soderbom, B. 2013. The effects of Risks and Shocks on Non-Farm Enterprise Development in Rural Ethiopia.World Development 45: 119136.

Salami, A, A. Kamara, Z. Brixiova. 2010.Smallholder Agriculture in East Africa: Trends, Constraints and Opportunities.Working Papers Series $\mathrm{N}^{\circ} 105$ African Development Bank, Tunis, Tunisia. 
Schumpeter, J.. 1965.Economic Theory and Entrepreneurial History. In Case, Aitken HG (ed) Explorations in enterprise. Harvard University Press, Cambridge, MA.

Schumpeter, J. 1942. Capitalism, Socialism, and Democracy. New York: Harper \& Bros.

Simeon, Djankov, Yingyi Qian, Gérard Roland, Ekaterina Zhuravskaya. 2007. What Makes a Successful Entrepreneur? Evidence from Brazil.

Singh, G., R. Belwal. 2008. Entrepreneurship and SMEs in Ethiopia: Evaluating the role, prospects, and problems faced by women in this emergent sector.Gender in Management: An International Journal 23(2):120-136.

Smallbone, D., et al. 2003, The Future of Europe's Rural Periphery: the Case of Devon and Cornwall, Centre for Enterprise and Economic Development Research (CEEDR), University Business School, Middlesex.

Smith, HL, Bagchi-Sen, S. 2012. The research university, entrepreneurship and regional development: Research propositions and current evidence. Entrepreneurship \& Regional Development 24 (5-6): 383-404.

Soo Hoon Lee, Phillip Phan. 2008. Initial thoughts on a model of rural entrepreneurship in developing countries: World Entrepreneurship Forum.

Stathopoulou, S., D. Psaltopoulos, D. Skuras. 2004.Rural Entrepreneurship in Europe: a research framework and agenda. International Journal of Entrepreneurship Behaviour \& Research 10(6):404-425.

Sundaram-Stukel R, K. Deininger, S. Jin. 2006. Fostering growth of the rural non-farm sector in Africa: The case of Tanzania. Selected Paper prepared for presentation at the American Agricultural Economics Association Annual Meeting, Long Beach, California, July 23-26, 2006.

Tobin, J. 1958. Estimation of Relationships for Limited Dependent Variables.Econometrica 26(1):24-36.

Trienekens, H.J. 2011. Agricultural Value Chains in Developing countries A Framework for Analysis. International Food and Agribusiness Management Review 14(2):51-82.

Tunberg, M. 2014. Approaching rural firm growth: a literature review.Journal of Enterprising Communities: People and Places in the Global Economy 8(4): 261-286. 
Verheul, I., A. van Stel, and R. Thurik. 2006. Explaining Female and Male Entrepreneurship at the Country Level. Entrepreneurship \& Regional Development 18 (2): 151-183.

Williams, C. 2009.The hidden enterprise culture.Entrepreneurship in the underground economy.Edward Elgar, Cheltenham, UK.

Witt, P. 2004. Entrepreneurs' networks and the success of startups.Entrepreneurship and regional development 16:391-412.

World Bank. 2015. SME Finance in Ethiopia: Addressing the missing middle challenge.

https://openknowledge.worldbank.org/bitstream/handle/10986/21 488/943650WP0Box380nt0Feb01002015040Web.pdf? sequence= 1 [Accessed on 24 August 2015]. 
Entrepreneurship Drivers in the Non-farming Sector

\section{Annex}

Table 2: Summary statistics

\begin{tabular}{|c|c|c|c|c|}
\hline \multirow{2}{*}{ Variable } & \multicolumn{2}{|c|}{ Rural } & \multicolumn{2}{|c|}{ Urban } \\
\hline & Mean & Std. Dev. & Mean & Std. Dev. \\
\hline Sex_HHH & .753 & .431 & .597 & .490 \\
\hline HH_Size & 5.100843 & 2.376692 & 3.695562 & 2.176561 \\
\hline HHH_age & 46.22038 & 15.31014 & 40.70248 & 15.47315 \\
\hline Credit_taken & .2764031 & .4472861 & .2091942 & .4068384 \\
\hline Shock_death & .0153476 & .1229495 & .0185759 & .1350563 \\
\hline shock_flood & .022269 & .1475794 & .002064 & .0453959 \\
\hline Shock_ill & .1035209 & .3046839 & .0799794 & .2713313 \\
\hline Shock_loss b & .0072224 & .0846899 & .0252708 & .1569868 \\
\hline Shock_drou t & .1014144 & .3019221 & .001032 & .0321163 \\
\hline RegionT & .1038218 & .3050752 & .1382156 & .3452151 \\
\hline RegionAF & .0309961 & .1733331 & .0170191 & .1293757 \\
\hline RegionAM & .2082456 & .4061145 & .1763796 & .3812411 \\
\hline RegionOR & .192898 & .394633 & .2140278 & .410252 \\
\hline RegionBG & .0340054 & .1812703 & .0061888 & .0784451 \\
\hline RegionSNNP & .2612098 & .4393601 & .1681279 & .3740763 \\
\hline RegionGM & .031297 & .1741455 & .013409 & .1150478 \\
\hline RegionHA & .0361119 & .1865968 & .0232078 & .1506019 \\
\hline RegionAA & 0 & 0 & .1531717 & .3602459 \\
\hline RegionDD & .0355101 & .185093 & .0536359 & .2253559 \\
\hline RegionSO & .0659043 & .2481521 & .0366168 & .1878676 \\
\hline Nvmarried & .025781 & .1585054 & .1711479 & .3767355 \\
\hline Mariedpoly & .040643 & .1974917 & .0051706 & .0717395 \\
\hline Divorced & .0597513 & .2370614 & .1096174 & .312493 \\
\hline Separated & .0133455 & .1147665 & .0263702 & .1602751 \\
\hline Widowed & .1410373 & .3481128 & .1437435 & .3509202 \\
\hline Mariedmono & .7194419 & .4493401 & .5439504 & .4981934 \\
\hline Orthodox & .4170458 & .4931454 & .6468459 & .4780737 \\
\hline Protestant & .2059448 & .4044517 & .1334023 & .3400969 \\
\hline Muslim & .3412193 & .4741908 & .2068252 & .4051338 \\
\hline Traditional & .0103124 & .1010404 & .0005171 & .022739 \\
\hline Pegan & .0084926 & .0917769 & .0010341 & .0321495 \\
\hline Wakifata & .0090992 & .0949691 & .0005171 & .022739 \\
\hline Reli_othr & .0006066 & .0246258 & .0020683 & .0454427 \\
\hline Catholik & .0072793 & .0850209 & .0087901 & .0933666 \\
\hline Illitrate & .8886191 & .314651 & .6252588 & .4841813 \\
\hline Basic_ifoe $\sim c$ & .0719272 & .2584065 & .1174948 & .3220924 \\
\hline Primary_1s c & .0197269 & .1390812 & .0517598 & .2215991 \\
\hline Primary_2n c & .014264 & .1185953 & .1195652 & .3245364 \\
\hline Second_educ & .0036419 & .0602472 & .0538302 & .2257408 \\
\hline VOC_TTC & .001214 & .0348261 & .0232919 & .1508681 \\
\hline College_educ & .000607 & .0246332 & .0087992 & .0934145 \\
\hline No. of obse. & 3295 & & 1932 & \\
\hline
\end{tabular}

EJBE Vol. 6 No. 2/2016 